\title{
Linguistic Archaeology: Tracking Down the Tasaday Language*
}

\section{Introduction ${ }^{1}$}

In July 1971 a report by Manuel Elizalde Jr., ${ }^{2}$ then Presidential Assistant on National Minorities in the Philippines (Elizalde and Fox 1971) to the Smithsonian Institution's Center for Short-Lived Phenomena from Southern Cotabato, Mindanao in the Philippines, informed the world of a small, isolated group of hunter-gatherers supposedly living in caves in the rain forests of southern Mindanao in the Philippines. The group of six families numbered approximately twenty-seven individuals, ranging in age from infancy to old-age, including a retarded male albino child with severe skin lesions and an elderly couple both of whom were said to be deaf-mutes. The group had a few metal tools, used stone tools, and were claimed to have no knowledge of agriculture or domesticated plants, including rice. They wore loin cloths, made either of old cotton fabric, bark cloth or the leaves of a ground orchid. They were said to have had no knowledge of tobacco or alcoholic drinks, but were familiar with betel nuts and chewed them with lime and a variety of leaves and bark from plants in their environment.

Initial reports claimed that prior to June 1971, when they were first contacted by members of PANAMIN at Mutuplung, a clearing at the edge of the rain forest, the Tasaday had been in contact with only one outsider, a hunter

Originally published as: Linguistic archaeology: Tracking down the Tasaday language. In Archaeology and language 1: Theoretical and methodological orientations, ed. by Roger Blench and Matthew Spriggs, 184-208. London and New York: Routledge. (1997) Also in http://aa2411s.aa.tufs.ac.jp/ reid/Tasaday/index.html.

1 All transcriptions are phonemic. The phonological inventory of Tasaday is identical to Blit and Kulaman Valley Manobo, with fifteen consonants and five vowels, alphabetized as follows: $2, a, b, d, \partial, e, g, h, i, k, l, m, n, \eta, o, p$ [f] $, s, t, u, w, y$. All Tasaday and Blit data are cited from my field notes, and Kulaman Valley data are cited from Errington and Errington (1981), but in phonemic transcription. Other languages such as Botolan Sambal, Binukid, Sarangani Manobo, Bontok, Ilokano, etc., are cited from either Reid $(1971,1976)$ or from field notes.

2 Prepared in collaboration with the late Robert Fox, then Chief Anthropologist of the National Museum of the Philippines, and Director of the Research Center associated with a private project to assist national minorities, known as PANAMIN, established by Elizalde. Editors' note: Elizalde died May 3, 1997. 
named Dafal, although they knew of two other forest groups, called respectively Sanduka and Tasafeng, with whom they intermarried. The contacts with Dafal occurred during his various hunting trips into the mountains where the Tasaday lived. Dafal was born in the nearest agricultural community to the Tasaday area: a place called Blit. The Blit community was the furthest expansion east from the Kulaman Valley of a group of Manobo whose language is referred to in the literature as South Cotabato Manobo. One other language-Tboli-is commonly spoken in the area, and most people in Blit are conversant with both languages. A full record of the events surrounding the 'discovery' of the Tasaday, and of the controversy that has accompanied these events, is found in Nance (1988).

The Tasaday, when first contacted by the PANAMIN group, supposedly spoke a language considerably different from either the Manobo or Tboli dialects spoken in Blit and the surrounding areas, although comparison of word lists taken by linguists and anthropologists soon revealed that the language spoken by the Tasaday was far more similar to the Manobo spoken in Blit than it was to Tboli.

Initial reports stated that apart from their contact with the hunter Dafal, they had had no 'recurring' contacts with other people, although they had seen the houses and fields of peoples who lived at lower elevations than themselves, presumably the Blit community which was at that time only about a three- to four-hour hike away from the caves to the west. A number of Blit individuals were involved with the initial contact arrangements when Elizalde first flew in, and have remained in close contact with them since. These include the leader of the Blit community, Datu? Dudim, ${ }^{3}$ and several members of his large family. Datu? Dudim's son by the second of his seven wives (Luan), a young man named Mafalu, learned to operate communications equipment for Elizalde's organization, PANAMIN, and assisted in other ways. It was Datu? Dudim's oldest daughter Sindi (by his first wife, Kelaya) who was persuaded to become the wife of the Tasaday Belayem, who, probably in his early twenties, had not been able to acquire a wife for himself from the traditional sources of Tasaday spouses. It was also Datu? Dudim's daughter Soléh (by his fifth wife, Filey) who

\footnotetext{
${ }^{3}$ Editors' note: Datu? Dudim died in August, 1999.
} 
became Belayem's second wife in the early 1980s, after Sindi failed to bear children. Datu? Dudim told me that he had seen the Tasaday in the forest during hunting trips in his youth, but that they had always run away from him.

\section{The Hoax Claims}

After the initial flurry of news reports, documentaries, and some preliminary investigative work by various scientists, including linguists, anthropologists, a botanist, a sociologist, etc., and the establishment by the Marcos government of a 19,000-hectare reservation in 1972 to protect the rain forest surrounding the Tasaday caves from the incursions of several logging companies, the Tasaday were left to resume their chosen way of life. In 1974, visitors were prohibited from entering the reservation without special permit, and for the next twelve years nothing more was heard of the Tasaday.

In 1986, news of the Tasaday reappeared in the media. A Swiss journalist, Oswald Iten, claimed to have visited the Tasaday in the aftermath of the overthrow of Marcos, in the company of a number of local individuals who told him that the Tasaday were not what they had been claimed to be, but were a mixed group of Manobos and Tbolis motivated by promises of land and money to act the part of cave-dwelling, stone-tool-using primitives whenever Elizalde required them to do so. Various other individuals had questioned the authenticity of the Tasaday prior to this, most notably the Filipino anthropologist Zeus Salazar (1971, 1973). However, it was Iten's report which spawned the virulent controversy that was first officially debated at a conference (the International Conference of the Tasaday and Other Urgent Anthropological Issues) at the University of the Philippines in 1986. At this conference, University of the Philippines anthropologist Zeus Salazar presented a series of genealogical charts which he claimed was evidence that the Tasaday were blood relatives (some of them college-educated) of various individuals living in communities outside of the rain forest. The genealogies however were not collected in the usual manner by interviewing the individuals concerned, but were reported to him on the eve of the conference by George Tanedo, a well-known son of an Ilokano settler in Maitum, part of the Tboli area. The real names of the individuals who supposedly participated in the scheme were given, with their corresponding Tasaday aliases. 
A second symposium was held as part of a conference in Zagreb in 1988 (The International Congress on Anthropological and Ethnological Studies), and in 1989 a third conference (a special Invited Session of the 88th Annual Meeting of the American Anthropological Association) to discuss the Tasaday controversy was held in Washington, DC. A number of papers, both pro and con (e.g. Berreman 1992), which were presented at the last conference were published in a volume (Headland 1992), and probably did little to change anyone's opinion on the status of the Tasaday. Headland's summary attempted to claim the middle ground between two diametrically opposed points of view, the one being that prior to Elizalde's involvement in the events there were no Tasaday people as such, they were a group of disparate individuals brought together from various communities who were instructed to rush to the caves, dress like primitives, and told how to act and what to say (and not to say) whenever they were required to be shown off to gullible journalists, prominent personalities (and scientists). The polar opposite of this point of view was that the Tasaday were remnants of some paleolithic population who had survived in isolation in the rain forest for perhaps thousands of years, or at least five to seven hundred years, based on one published glottochronological estimate (Llamzon 1989:61), without contact with peoples outside the rain forest.

At the Washington conference in 1989, a carefully prepared set of genealogies by Rogel-Rara and Nabayra (1992) which included each of the Tasaday as well as each of what were called the Tasaday poseurs, seemed to show conclusively that the Salazar genealogies were false. This, as well as the linguistic evidence presented in several papers (Molony 1992; Elkins 1992; Johnston 1992; Reid 1992), was suggestive that the Tasaday were in fact a separate ethnolinguistic group, distinct from either Blit Manobo or Tboli. Headland, however, claimed that it would have been impossible for the Tasaday to have lived in total rain-forest isolation without regular access to cultivated foods, especially the rice which was grown in the clearings around the Blit community.

\section{The Research Strategy}

I had been present at the 1988 conference in Zagreb, and was intrigued by the claims that were being made by those who said that the Tasaday were a 
hoax, and that all but two of the participants in the supposed charade were really Tbolis who could speak Manobo. I was puzzled as to why the supposed orchestrators of the hoax had required the whole group (including children) to speak Manobo, the language of the two-member minority, rather than Tboli, supposedly the language of the majority. However, be that as it may, if it were true that they were mainly Tboli speakers, evidence should be forthcoming from the data that was first gathered by linguists and anthropologist in 1971 and 1972, to support it. There should be clear evidence of borrowing from Tboli.

After examining all of the early lists collected in 1971, I presented a paper at the Washington conference to show that I could find no evidence at all of Tboli influence, and that the types of responses given by the Tasaday to the field workers' questions about their language suggested a degree of naïveté that would not have been present if the respondents had been other than what they claimed to be.

At the Washington conference, results of a three-day visit to the Tasaday by a Filipino husband and wife linguist team, Cesar and Araceli Hidalgo, were presented. They claimed that they had collected data from the Tasaday which were considerably different from that which was collected by the linguist Carol Molony twenty years earlier. They further claimed that their data represented an older form of the language, one which was spoken prior to the considerable language changes that had resulted from their contact with the Blit Manobos following the initial contacts with them in 1971. The Hidalgos believed that by 1972 the Tasaday were speaking a pidginized form of Manobo and that the evidence suggested a very long period of independent development from other Manobo languages.

In 1989, I had the opportunity to also collect data from some of the Tasaday during a ten-day visit to the Tboli area (Reid 1993). Although my data did not completely coincide with that presented by the Hidalgos, there was sufficient overlap with their data, in forms which were supposedly old terms not recorded in the 1970s, that I decided to spend an extended research period with the group. My plan was to try to find out as much as possible about the language that they currently speak, and as much as could be discovered about the Tasaday language as they claimed to have spoken it twenty-five years ago. I 
would compare these forms of speech with that spoken by the nearest agricultural community to Tasaday, the Manobo dialect of Blit, for which almost no data was at that time available, and with the Manobo dialect of Kulaman Valley (KLM), often referred to in the literature as Southern Cotabato Manobo, for which I had available an unpublished dictionary of about 3,500 entries (Errington and Errington 1981), as well as a number of published articles on phonology, morphology, and syntax written by the Erringtons and other members of the Summer Institute of Linguistics who had lived in the Kulaman Valley area. I hoped furthermore to be able ultimately to try to identify etymological sources for those terms that were said to be old Tasaday and for which no obvious cognates existed in the surrounding languages.

The project was planned to take place over a period of three years. The first fieldwork stage consisted of three periods of residence with the Tasaday totaling approximately two and a half months between February and July $1994 .{ }^{4}$ A second period of fieldwork was conducted during the summer of $1995,{ }^{5}$ and a third trip in the summer of 1996. This chapter is in effect a report of the results of the analysis that I have been able to do of the data collected during the first half of 1994.

\section{The Field Work}

The first month of fieldwork, from mid-February to mid-March 1994, was conducted at the site where the majority of Tasaday now live. This is a small cleared valley about twenty minutes' walk from the caves which they still claim as their home. The place is called magtu ilinan, literally 'New Learning', and sometimes by a term, obviously adapted from English, nu bəliginin 'New Beginning', and is about a two-day hike north-west from Lake Sebu.

I was taken directly to the thatch-roofed, split palm and bamboo home of Udelen and his wife Dul and their family. In 1971, this couple had only two small sons. Dul had delivered her first daughter, Okon, the following year.

4 I am grateful to the University of Hawai'i for granting me a full-time research position during the Spring and Summer, 1994, that enabled me to conduct the first stage of the project.

5 A paper reporting on this period of fieldwork, during which some of the tapes secretly recorded in the Tasaday caves in 1972 were transcribed and translated with the assistance of the Tasaday, was presented to the $4^{\text {th }}$ Pan-Asiatic Linguistics Conference (Reid 1996). 
When I arrived, Dul was nursing her tenth child, and Okon, now married, was also in the home, mourning the loss of her first child, stillborn only days prior to my arrival. Their oldest son, Sius, lived in an adjacent house with his wife and child; Maman, the second son, who had married a young Tboli woman, was living away from the group with his wife's family. He periodically visited during the time that I was there. His first child was born a couple of months after my arrival. The other children of the family, Diha?, Sungo, Talihin, Dihut, Klohonon, and Fakal also lived in the house, except during periods when the older children accompanied their father on trips to gather palm pith, or to another area of the forest that they were cutting back to form a new kaingin.

Also living with the family during the period of my stay there was a Belgian, Pascal Lays, a member of the London-based organization Survival International. He had been living on a fairly regular basis with the Tasaday for more than two years, studying their language and culture, and making extensive collections of botanical and zoological specimens from the rain forest. He was able to communicate quite well with the Tasaday in the language that they are presently using to outsiders as well as among themselves. Lays told me that it was the language of the Blit Manobos, from whence most of the outside wives of Tasaday men have come since 1972. He agreed to assist me as interpreter during the early stages of my research in that community.

Since my primary object was to discover as much as possible about the language spoken prior to 1971, I decided to work with Belayem, now a man probably in his late forties or early fifties. He had the reputation of being the most articulate of the Tasaday even when the group was first studied. He was fully aware of the controversy that surrounds the group, and readily consented to be my main Tasaday language assistant, although Dul, and often other younger Tasaday, were also present at most of the language gathering sessions. Bilengan, one of the older Tasaday men who also lived in Magtu Ilingan and is now becoming deaf, periodically sat in although he did not actively participate in the data gathering.

Datu? Dudim's son Mafalu was invited to come from Blit and was requested to assist by providing Blit Manobo equivalents for the Tasaday terms that Belayem would give me. Mafalu was one of the few available Manobo-speaking Blit villagers who could communicate also in Tagalog. He was, in addition, the 
brother-in-law (twice over) of Belayem, and had been in contact with the group for at least the last twenty-three years.

I conducted fairly short morning and afternoon sessions for approximately one month with Belayem and Mafalu, gathering supposedly old Tasaday forms and their Blit Manobo equivalents and recording several Tasaday and Blit texts. A second period of research lasting about one month (April 1994) was held in Mutuplung, close to the site of the first contact between the group and Elizalde. Belayem and his two Blit wives had decided to begin a new settlement there because of its associations and because they would be closer to their two older children now attending grade school about a kilometer away in Blit. When I arrived, clearing had begun on a small ridge above a creek, and a bamboo platform had been erected with palm leaf walls and temporary roof for protection from the constant rains. Over the next three weeks groups of relatives and friends came from Blit on an almost daily basis to complete the building of the house, while with Belayem and Mafalu I continued investigations into the similarities and differences between their two languages. A third period of research lasting about two weeks (July 1994) was conducted in Blit.

\section{The Data}

From the outset, the data received from Belayem seemed to confirm the claim that prior to their contact with outsiders they were indeed using a very different form of speech than that used by the Blit. For almost every Blit word that a Tasaday equivalent was requested, a Tasaday translation was given, and Mafalu would often claim that the term provided was not known to him, or that it had a different meaning in Blit.

Before long, however, I began to become suspicious of the data that Belayem was giving. I noted that he was making a conscious effort to distinguish the forms he gave me from those of Mafalu. Sometimes he would do this by simply switching the affixation of a verb, or by using a different pronominal ending. At other times, it seemed that the forms that he was giving me were deliberate phonological distortions of Blit forms. Data sets 1-56 (see Appendix) are examples of some of these items. However, systematic comparison of the data with Kulaman Valley Manobo showed that at least some of the forms (e.g., sets 57-60) corresponded exactly to their Kulaman Valley cognates, and it was 
the Blit form that was phonologically different. This kind of evidence suggested that the irregular forms were not entirely the result of conscious distortion, but rather that at least some of the cases were the result of unconscious, sporadic phonological change. Nevertheless, by the end of the second period of residence in the area I was convinced that some of Belayem's forms, which were completely different phonologically from their Blit equivalents, were indeed fabricated by him.

Between the second and third periods of residence with the Tasaday, the task of systematically entering the data into a database was begun, ${ }^{6}$ so that the material could be compared with the Manobo spoken in the Kulaman Valley. At the end of this period, I had a list of about 750 lexical items supposedly used by Tasaday prior to 1971 that were unknown to Mafalu. An additional list of 1,200-1,500 items formed a second lexical set that were known to both Belayem and Mafalu, and constituted the Blit Manobo corpus.

At this point the Manobo dictionary was searched for possible cognates of the 'unique' old Tasaday data, i.e., those forms that Mafalu had claimed were unknown to him. To my considerable surprise I found that a large number (approximately 300) of the items that had seemed to be completely new coinages by Belayem had similar forms in the Kulaman Valley dictionary. A small set of these is given in the Appendix (61-66). However, there remained a large number of forms that had no equivalents in any of the lexical sources then available to me, forms that are potentially evidence of fabrication; but on the other hand such forms may be genuinely unique, old Tasaday terms. A short list of these items is given in datasets 67-86.

A comparison with other Philippine languages of a number of the Tasaday forms that have no Blit or Kulaman Manobo equivalents, revealed that there are a number that do have possible cognates in other Manobo languages (sets $88,90,92,93$ ), and some that have cognates with languages outside the Manobo group (sets 89, 91, 94, 95, 96), but not with Manobo languages. Such forms are potentially of great value in establishing the relative length of time that the Tasaday language may have been developing independently from other Manobo languages; that is, they are possibly retentions of forms that have

6 The program used was Shoebox, a database program for linguists developed by members of the Summer Institute of Linguistics. 
been lost in other Manobo languages but which are still retained in Tasaday. At this point, however, the possibility of their being borrowings, or alternatively that cognates will turn up in other Manobo languages, must still be considered.

Of the forms that were known to both Belayem and Mafalu, a considerable number showed some kind of semantic change. Usually a Tasaday form was claimed to have a wider reference than its Blit equivalent (see datasets 97-116). A few sets show a narrower reference (117-18), while others show a clear semantic shift (119-29).

One of the features of Tasaday that has been mentioned a number of times in the literature to support the claim of an extended period of isolation from other groups is the lack of borrowed terms from Spanish or other languages for concepts (such as 'war'), or for post-western contact cultural items that are a ubiquitous part of Blit and other surrounding languages but which were supposedly unknown to the Tasaday prior to 1971. Typically in the Philippines, terms for such items are adapted from a donor language, either Spanish or more recently English. Tasaday is unusual among Philippine languages in that not only are such forms absent, but that even today there is a clear avoidance of them. Belayem consistently used either paraphrastic expressions or metaphorical extensions of 'native' Tasaday terms for items that are claimed to have been introduced to the Tasaday since 1971. Data sets 130-53 are examples of some of these. The data provided by Belayem are unusual in other respects. Data sets 154-73 are paraphrastic expressions for terms that are not introduced concepts, but are items that languages typically have single lexical items for, although at least the term for 'river' (154) is in many languages simply the term otherwise translated as 'water'. This data is suspect and may have been constructed by Belayem to further distinguish his dialect from that of Blit. His choice of one of the terms of certain synonym sets (such as those in 174-5) found in both Blit and Kulaman, while denying the use of the other, was also a practice admitted by Dul to Pascal Lays while I was there as a means of distinguishing the two dialects. Although now only the first member of such sets is used by Belayem, the other member was commonly recorded by earlier researchers, such as Molony (1976), and it still appears in certain fixed expressions such as 133, 143. 
The absence of Spanish borrowings has never seriously been challenged, but there are a couple of forms that probably show them. Early word lists, such as that by Molony (1976: 85), give the word layit for 'sky', a term which has cognates in Blit, Kulaman, and many other Philippine languages. Presently Belayem uses the term lugabuan 'sky'. This is almost certainly a paraphrastic expressions meaning 'place of the moon' combined from a Spanish term widely distributed throughout the Philippines, lugar 'place' with regular loss of the final $l$ (from $r$ ) plus what appears to be the Tagalog form buwan 'moon'. It is no doubt a term of recent provenance. ${ }^{7}$ The other form epe? has an older provenance in the group, in that it appears in Molony (1976: 78). It is transcribed there as Refe? 'spirit', with Pefe? ilib 'owner of the cave, the white-haired spirit'. This is probably the Spanish form also widely distributed in Philippine languages, jepe 'chief, leader', there being no other Philippine terms meaning 'spirit' or 'owner' with which it could reasonably be associated.

There also appears to be some Tboli influence on some of the lexicon and also the morphology of some of the verb forms that Belayem uses. In Tboli, the regular development of an earlier *a vowel is Tboli o. For example, Tboli hulo? $<$ *pula? 'red', Tboli sobow < *sabaw 'soup', Tboli Powoy < *2abay 'boat', Tboli kulon < *kudan 'rain', Tboli holol < *palad 'palm of hand', etc., Although there is no clear evidence of borrowing of lexical items from Tboli into Tasaday, several forms which are probably new developments by Belayem show $o$ for expected $a$, and are possibly the result of phonological influence from Tboli (e.g., 176-177). The first of this pair is a metaphorical extension of the cognate term in Kulaman, but has an unexpected $o$ vowel in the final syllable. The second, pondol, is apparently a reduced paraphrastic expression, consisting of the first three segments of each of the words in the phrase panaw dalan, literally 'walk path', but with the vowels altered as indicated above. It should be noted however that the words themselves are not Tboli.

Tboli influence on verbal morphology is seen in Belayem's use of the -in- affix. In Tboli, the affix does not mark completive aspect as it does in Kulaman and other Philippine languages. It is simply the marker of what is commonly

Editors' note: Subsequent research with a speaker of Kulaman Valley Manobo, revealed that this analysis is incorrect. The word is acutally lugabu with a locative suffix -an, and was not a compound of Spanish and Tagalog as had originally been suspected. 
called an 'object focus' verb, and can therefore appear on verbs that have future time reference, and even on imperative forms. This use of the infix is not unique to Belayem. It is commonly heard also in Blit.

\section{Conclusions}

The data discussed above appear to be of two very different kinds and lead to two quite different conclusions. A person who is skeptical of the authenticity of the Tasaday would focus on one set and surely jump to the conclusion that here is the evidence that is needed to settle the case: distorted forms, borrowings from Spanish, influence from Tboli, apparent coinages, and a host of paraphrases apparently developed by Belayem to make his language different from that of his Blit neighbors. Such a conclusion would have to disregard the other set; namely, the considerable body of data that apparently does not have Blit equivalents (at least not according to Mafalu), but for which corresponding forms can be found in either Kulaman Valley - an area which Belayem has never visited-or most importantly, in neither Blit nor Kulaman but in other Manobo languages or even in more distant Philippine languages.

What then is the explanation for the first set? There is no doubt that much of the data that Belayem gave me were indeed made up for the occasion, or are part of a 'new Tasaday' that he had produced not only for me but also for the Hidalgos in their research. Although Belayem has an excellent memory for such forms, many that he had given me in the earlier periods of my fieldwork were rejected by him as being not Tasaday when I rechecked them at later stages of the project.

At the root of this apparent obfuscation is the obviously deep-rooted sense of identity that the Tasaday (not only Belayem) have of themselves. In the twenty-three years since their first publicized meeting with outsiders, not a single member of the original Tasaday group has 'recanted', even though the supposed motivation for their formation as a group, the all-powerful influence of their mentor, Elizalde, has long since faded. The group lives in poverty, and has no reason to continue the charade, if indeed there was one. Time and again, Belayem and other members of the group expressed frustration and anger over the questions that have been raised about their authenticity. The English term 'fake' is now a part of the Tasaday vocabulary. 
Belayem realized from the beginning of the fieldwork that my object was to examine the relationship between his earlier language and that of Blit. He did not know whether I was looking for evidence to further cast doubt on their authenticity, but probably suspected it. He never, for example, allowed me to visit the actual cave site, less than twenty minutes' hiking from the Magtu Ilingan settlement, since he knew that others who had been there had left after seeing the caves and published negative reports about the group.

I consider that the efforts Belayem went to in order to create differences between his Tasaday language and that of Blit were directly the result of his knowledge of the hoax controversy and were for the purpose of attempting to validate himself and the other members of the group as a distinct ethnolinguistic group.

A number of interesting parallels can be drawn between the Tasaday in south-east Asia and another ethnolinguistic group that has recently been described-the Minor Mlabri, an 'evasive' and 'extremely shy' group of huntergatherers (only eleven surviving members), living in the border area between North Thailand and Laos (Rischel 1995). In many parts of the description of this group one could replace the name Minor Mlabri with Tasaday without doing violence to the facts. Rischel describes them as follows:

They have in the past lived on food they could find by moving about in the dense forests of the high mountains without settling for more than a few days in any particular place. Until recently their shyness and ability to hide in the forest has prevented their culture and language from being exposed to outsiders except for a few encounters with expeditions (Rischel 1995:23)

He cites Boeles's (1963:150) description of them as 'a group of people who have not known a stone age and thus have no pottery, who do not make their own clothing, who do not practice agriculture, who do not build houses, and who do not wear ornaments'. He suggests that, 'their culture may even reflect regressions from more developed stages to a survival culture' (Rischel 1995:22).

There is another, larger group of Mlabri (the ' $\beta$-Mlabri'), previously studied by Rischel, hence the term Minor Mlabri (or ' $\alpha$-Mlabri') for the smaller group that he describes. The larger group have given up a hunter-gatherer lifestyle. Rischel says that they are rapidly adjusting to a peasant life since it is becoming impossible to sustain life on the things they can gather in the forest. The $\alpha$ - 
Mlabri on the other hand, still prefer to stay in the forest as much as possible in an attempt to survive as part-time hunter-gatherers (Rischel 1995:36).

The relationship between the two Mlabri groups parallels in several respects the relationship between the Tasaday and the Blit groups. Rischel states:

The relationship between the two varieties of Mlabri is enigmatic. On my first encounter with speakers of Minor Mlabri, I was intrigued by the paradoxical situation that a large proportion of the words they used in everyday communication were totally unknown to me although they clearly spoke the very language I had been studying for several years together with my colleagues. I was further intrigued by finding that there was virtually no difference in segmental phonology between the two varieties of Mlabri although they differed strikingly in prosody (rhythm and intonation) as well as lexicon ...

Structurally, the two kinds of Mlabri are so extremely close that one may speak of sub-dialects of one dialect. The two varieties have almost the same phonology and morphology, and to the extent that lexical material is shared, it occurs in largely the same phonological shape... There are SEGMENTAL differences between $\alpha$-Mlabri and $\beta$-Mlabri in the pronunciation of several words, but there is also idiolectal variation... The lexical differences may have at least three different causes. They may in some cases reflect the existence of synonymous (or nearsynonymous) word pairs in Old Mlabri. Synonymy was then lost as one variety retained only one word, and the other variety retained only the other synonym: ... there are several instances where one variety of Mlabri has an ordinary MonKhmer etymon whereas the other variety has a word exhibiting peculiar features, suggesting that it is a deliberate innovation... Often a word used in one variety is known but considered obsolete or stigmatized by speakers of the other variety. In several instances speakers even deny any knowledge of a word used by the other group. The linguistics attitudes toward lexical materials is a complex issue... The differences in lexicon are so great that one would not expect easy intercommunication between the two groups... This lexical divergence, as contrasted with the structural similarity of the two varieties of Mlabri, must be recent but is so strong that it suggests an effort to mark the distinction between the $\alpha$ - and $\beta$-Mlabri. (Rischel 1995:16, 26-7; bold emphasis added)

The linguistic characteristics noted by Rischel which distinguish the two Mlabri dialects are precisely those that are found between Blit and Tasaday; namely, almost identical phonology and morphology; lexicon which is very divergent between the two groups suggesting, at least in some cases, (relatively) recent deliberate innovation in order to mark the difference between the two groups. The two situations are, however, not completely parallel. The two Mlabri groups continue to avoid one another and to maintain their linguistic distinctiveness, whereas the Blit and the Tasaday now intermarry, and are 
merging as a single group, with the children of Tasaday families studying in school in Blit, and speaking Blit Manobo in the home rather than using the Tasaday forms of their parents, just as the children of mixed Tasaday-Blit families do.

So what was the language of the Tasaday like in 1971? Was the conclusion of early researchers correct that Tasaday at that time was simply a close variant of Blit Manobo, or of Kulaman Valley Manobo, which was the conclusion that must be drawn from the Molony study? Or was there really a body of lexical differences that were never reported at that time simply because by the time Molony got there in 1972 they had already adapted to the Blit language and her data reflects the language that they had begun to use in place of the older forms that others didn't understand?

Some tapes that were secretly made in the caves during Elizalde's first and subsequent visits to the Tasaday caves have been made available to me. Rough English translations of parts of these tapes were published in Nance (1988), but no transcriptions were made of the actual language used. Recent research during which these tapes were transcribed and translated (Reid 1996) shows that although at that time there were a number of distinctive lexical forms that were commonly being used by the Tasaday, many of the forms that Belayem commonly uses today and which he claims to be 'real' Tasaday are probably recent innovations and serve the purpose of distinguishing his dialect from that of his Blit neighbors. Nevertheless, the evidence of clearly unique innovations in Tasaday which predate the initial contacts, and the retention of older forms in Tasaday which have apparently been lost in neighboring Manobo languages, indubitably establish the Tasaday as a distinct ethnolinguistic group.

\section{Abbreviations}

Language abbreviations
BON.............. Bontok
ILK................ Ilokano
ITGB ............. Binongan Itneg
KLM............... Kulaman
MBOBKD ......... Binukid Manobo
MBOSRN......... Sarangani Manobo
PMP............. Proto-Malayo Polynesian
SBLBT ............. Botolan Sambal

\section{Other abbreviations}

euph ...... euphemism

k.o......... kind of

loc. ........ location

var......... variant 
SML ................Samal

SubS............... Sindangan Subanun

TAG ............... Tagalog

TBL................ Tboli

TSD................ Tasaday 


\section{References}

Berreman, Gerald D. 1992. The Tasaday: Stone age survivors, or space age fakes? In The Tasaday controversy: Assessing the evidence, ed. by Thomas N. Headland, 21-39. The American Anthropological Association Special Publication No. 28, Scholarly Series. Washington, DC: The American Anthropological Association.

Boeles, J. J. 1963. Second expedition to the Mrabri of North Thailand ('Kohn Pa'). Journal of the Siam Society 50:133-160.

Elizalde, Manual, Jr., and Robert B. Fox. 1971. The Tasaday forest people. A data paper on a newly discovered food gathering and stone tool using Manubo group in the mountains of South Cotabato, Philippines. Typescript. Washington, DC: Smithsonian Institute for Short-Lived Phenomena. Published under the same title in Readings on the Tasaday, ed. by Virginia B. Dandan, 2-12. Tasaday Community Care Foundation Publication No. 1. Manila: Tasaday Community Care Foundation.

Elkins, Richard E. 1992. The Tasaday: Some observations. In The Tasaday controversy: Assessing the evidence, ed. by Thomas N. Headland, 117-29. American Anthropological Association Special Publication No. 28, Scholarly Series. Washington, DC: The American Anthropological Association.

Errington, Ross, and Ellen Errington. 1981. Cotabato Manobo dictionary. Unpublished computer printout. Manila: Summer Institute of Linguistics.

Headland, Thomas N., ed. 1992. The Tasaday controversy: Assessing the evidence. American Anthropological Association Special Publication No. 28, Scholarly Series. Washington, DC: The American Anthropological Association.

Johnston, E. Clay. 1992. The Tasaday language: Is it Cotabato Manobo? In The Tasaday controversy: Assessing the evidence, ed. by Thomas N. Headland, 144-56. Special Publication No. 28, Scholarly Series. Washington, DC: The American Anthropological Association.

Llamzon, Teodoro A. 1989. The Tasaday language so far. In Readings on the Tasaday, ed. by Virginia B. Dandan, 54-64. Tasaday Community Care 
Foundation Publication No. 1. Manila: Tasaday Community Care Foundation.

Molony, Carol H. 1976. (with the collaboration of Dad Tuan) Further studies on the Tasaday language: Texts and vocabulary. In Further studies on the Tasaday, ed. by Douglas E. Yen and John Nance, 13-96. PANAMIN Foundation Research Series No. 2. Rizal, Philippines: Makati. Reprinted in Readings on the Tasaday, ed. by Virginia B. Dandan, 85-168. Tasaday Community Care Foundation Publication No. 1. Manila: Tasaday Community Care Foundation.

Molony, Carol H. 1992. The Tasaday language: Evidence for authenticity? In The Tasaday controversy: Assessing the evidence, ed. by Thomas N. Headland, 107-16. American Anthropological Association Special Publication No. 28, Scholarly Series. Washington, DC: The American Anthropological Association.

Nance, John. 1988. The gentle Tasaday (2nd ed.). Boston: David R. Godine.

Reid, Lawrence A. 1971. Philippine minor languages: Word lists and phonologies. Oceanic Linguistics Special Publication No. 8. Honolulu: University of Hawai'i Press.

Reid, Lawrence A. 1976. Bontok-English dictionary, with English-Bontok finder list. Pacific Linguistics C-36. Canberra: Research School of Pacific Studies, Australian National University.

Reid, Lawrence A. 1992. The Tasaday language: A key to Tasaday prehistory. In The Tasaday controversy: Assessing the evidence, ed. by Thomas N. Headland, 180-93. American Anthropological Association Special Publication No. 28, Scholarly Series. Washington, DC: The American Anthropological Association.

Reid, Lawrence A. 1993. Another look at the language of the Tasaday. Keynote Lecture presented to the $3^{\text {rd }}$ Annual Conference of the Southeast Asian Linguistic Society (SEALS III), Honolulu, Hawai'i, May 10-17, 1993.

Reid, Lawrence A. 1996. The Tasaday cave tapes. Paper presented to the $4^{\text {th }}$ International Pan-Asiatic Linguistics Conference, Bangkok, Thailand, January 8-10, 1996. (Published as: The Tasaday tapes. In Pan-Asiatic Linguistics: Proceedings of the Fourth International Symposium on Languages 
and Linguistics, Vol. V:1743-1766. Salaya, Thailand: Institute of Language and Culture for Rural Development, Mahidol University at Salaya (1996).

Rogel-Rara, Amelia, and Emmanuel S. Nabayra. 1992. The genealogical evidence. The Tasaday controversy: Assessing the evidence, ed. by Thomas N. Headland, 89-196. American Anthropological Association Special Publication No. 28, Scholarly Series. Washington, DC: The American Anthropological Association.

Rischel, Jørgen. 1995. Minor Mlabri: A hunter-gatherer language of Northern Indochina. Copenhagen: University of Copenhagen, Museum Tusculanum Press.

Salazar, Zeus A. 1971. Footnote on the Tasaday. Philippine Journal of Linguistics 2(2):34-8.

Salazar, Zeus A. 1973. Second footnote on the Tasaday. Asian Studies 11(2):97-113.

\section{Appendix: Tasaday Data}

\section{Possible phonologically distorted Tasaday forms}

1. Tasaday be?e? 'grandparent, grandchild'

Blit bebe? 'grandparent, grandchild'

2. Tasaday bali?agay ' 'molar'

Blit bi?agay, KLM biiigay 'molar'

3. Tasaday bikat (var. dikat) 'sticky'

Blit, KLM limakat 'sticky'

4. Tasaday bulas 'semen'

Blit, KLM bulos 'semen'

5. Tasaday bulat 'flower'

Blit, KLM bulok 'flower'

This phonological distortion by infixation of -əl- is identical to that used by Belayem in his pronunciation of the English word 'beginning' in the sitio name nu baliginiz ('New Beginning'), as well as in other items such as taligasa 'other' (no. 50), and a subsequently rejected variant of ku?ku? 'cough' (no. 91).

9 Both Tasaday pronunciations differ from the Blit and Kulaman forms, but at least dikat has cognates distributed widely throughout the Philippines, including other Manobo languages. Cognates with an initial bilabial stop (but usually voiceless) are also found throughout the archipelago (see Reid 1971: 140). The TSD $d$ - / BLT, KLM l- correspondence seen here is, however, also found in no. 7 datzk 'leech', where it is the $l$ - initial form which has greater historical validity. 
6. Tasaday butəd (var. libutəd) 'k.o. edible wood grub living in sago palms'

Blit gutəd basag 'k.o. edible wood grub living in sago palms'

7. Tasaday datzk 'k.o. leech'

Blit limatək 'k.o. leech'

8. Tasaday dәрәп 'to be next to one another'

Blit latan 'to be next to one another'

9. Tasaday alam (əg-) 'feel sick', (nək-) 'menstruate'

Tasaday ala? 'pain, injury'; KLM ola? 'crack'

10. Tasaday gədub (var. kedub) 'hot' (weather); 'fever'

Blit, KLM adup 'hot' (weather); 'fever'

11. Tasaday gipis (var. nigpis, lugpipi?) 'thin'

Blit nipis 'thin'

12. Tasaday haya?haya? (var. kaya?kaya?) 'knee'

KLM kaya?kaya? 'knee'

13. Tasaday iyub 'back of a person'

Blit, KLM iyug 'back of a person'

14. Tasaday kayampey 'hawk'

Blit kayamba 'hawk'

15. Tasaday kəbugat 'k.o. bird'

Blit bugat 'k.o. bird'

16. Tasaday kalawawan (var. lawawan) 'body'

Blit lawa 'body'

17. Tasaday kuməlukesan 'old man, old woman'

Blit lukas 'old man, married man'; KLM lukas 'old man, old woman'

18. Tasaday lakipas 'k.o. civet cat'

Blit kipas 'k.o. civet cat'

19. Tasaday lambuyug 'k.o. bumblebee'

Blit tabulog 'k.o. bumblebee'

20. Tasaday labaw 'to swell, of an injured limb or a flooded river'

Blit, KLM labag 'to swell, of an injured limb or a flooded river'

21. Tasaday lagame? 'noise of tearing'

Blit logisi? 'noise of tearing'

22. Tasaday logka? 'to depart; to leave'

Blit, KLM lagkan 'to depart; to leave'

23. Tasaday loha 'testicle'

Blit, KLM laha 'testicle'

24. Tasaday ləkotok 'to boil, bubble'

Blit, KLM lukotok 'to boil, bubble'

25. Tasaday ləkud (var. səkud) 'flesh, muscle'

Blit, Klm əkud 'flesh, muscle'

26. Tasaday lamol 'rattan fruit'

Blit limulan 'rattan fruit'

27. Tasaday lopa? 'arm span, space between the tips of one's outstretched arms' Blit lipo 'arm span, space between the tips of one's outstretched arms' 
28. Tasaday libal 'to throw away, throw out'

Blit diwal 'to throw away, throw out'

29. Tasaday linabu? ${ }^{10}$ 'to fall'

Blit, KLM nabu? 'to fall'

30. Tasaday lugayan 'parent-in-law; co-parent-in-law'

Blit, KLM nugayan 'parent-in-law; co-parent-in-law'

31. Tasaday lugkip 'to have a piece cut out'

Blit lugkab 'to have a piece cut out'

32. Tasaday lugkug 'hunched, stooped'

Blit logkog 'hunched, stooped'

33. Tasaday lugpayas 'nice, bright, clear, good weather, smooth, light, beautiful' Blit lugkayat 'nice, bright, clear, good weather, smooth, light, beautiful'

34. Tasaday lumitan 'k.o. moss'

Blit lumut 'k.o. moss'

35. Tasaday mə?ambəm 'man'

Blit, KLM mə?ama 'man'

36. Tasaday ma?itas 'crow'

Blit ma?itas 'crow, dark feathered domesticated chicken'

Blit, KLM uwak 'crow'

37. Tasaday nadag 'odor; smell, good or bad'

Blit, Klm yadag 'odor; smell, good or bad'

38. Tasaday pulut 'to tie, as a string, the top of a skirt'

Blit, KLM sigpalut 'to tie, as a string, the top of a skirt'

39. Tasaday pundan 'buttocks'

Blit, KLM punuk 'buttocks'

40. Tasaday saluman 'shadow'

Blit, KLM aluך 'shadow'

41. Tasaday saluwaga 'k.o. snake'

Blit suwaga 'k.o. snake'

42. Tasaday səlu?uy 'hat'

Blit sala?uy 'hat'

43. Tasaday sinom 'mole on one's body'

Blit, KLM sonam 'mole on one's body'

44. Tasaday susu? 'breast'

Blit susu 'breast'

45. Tasaday takəwəs 'stomach'

Blit takuwan, takuwis, KLM takuwas 'stomach'

46. Tasaday tayag 'to nod one's head'

Blit tayu?, KLM tayu 'to nod one's head'

KLM tayad 'to shake uncontrollably, of one's head or hands'

10 This Tasaday form may be a reflex of an older form of the Manobo cognates. Cf. SML labu, and SuBS labu? 'to fall'. 
47. Tasaday tawawan 'person'

Blit, Klm staw 'person'

48. Tasaday təkəmu? 'to grab'

Blit kamu? 'to grab'

49. Tasaday tolagkab 'to lie on one's stomach'

Blit, KLM lagkab 'to lie on one's stomach'

50. Tasaday taligzsa 'other'

Blit tigasa 'other'

51. Tasaday tolub 'belch'

Blit tala?iyub 'belch'

52. Tasaday tigdudu? (var. tignudu?) 'index finger'

Blit tigtudu?, KLM katudu? 'index finger'

53. Tasaday toko? 'short'

Blit, KLM poko? 'short'

54. Tasaday tug?inəp 'dream'

Blit tigPinəp, KLM tagə?inəp 'dream'

55. Tasaday tulu 'fingernail, toenail'

Blit, KLM sulu 'fingernail, toenail'

56. Tasaday tuyal (var. tomal) ${ }^{11}$ 'nape of neck'

Blit, KLM tajal 'nape of neck'

\section{Phonological change in Blit but NOT in Tasaday}

57. Tasaday kumabus 'rib cage'; KLM kumabus 'lower ribs'

Blit kamabus 'lower ribs'

58. Tasaday, KLM səgələt 'sound of creaking, grinding'

Blit salagak 'sound of creaking, grinding'

59. Tasaday, KLM baha?ən 'to sneeze'

Blit ba?an 'to sneeze'

60. Tasaday, KLm lipadə刀 'to close one's eyes'

Blit pemidey 'to close one's eyes'

Tasaday forms shared with Kulaman, but NOT with Blit

61. Tasaday, KLM olad (-um-) 'sink in water, set (of the sun)'

Blit sandəp, agdaw 'sunset'

62. Tasaday, KLM hibat 'lie down on one's back'

Blit daga? 'lie down on one's back'

63. Tasaday lagas 'female genitals'; KLM lagas 'seed, fruit; female genitals (euph)'

Blit, KLm bati? 'female genitals'

64. Tasaday, KLM pə⿱一𫝀yab 'yawn'

Blit kaluyab 'yawn'

${ }^{11}$ Variant forms with loss of final $-l$ were both recorded. This phonological process commonly occurs in both Blit and Tasaday. 
65. Tasaday, KLM alat 'space between two objects' Blit tiwada? 'space between two objects'

66. Tasaday, KLM sagodoy 'drag; pull something' Blit honat 'drag; pull something'

\section{Possible Tasaday unique forms}

67. Tasaday angel 'angry' Blit, KLM bulit 'angry'

68. Tasaday bələyus 'nose' Blit, KLM idup 'nose'

69. Tasaday baliboy 'child, young' Blit, KLM anak; bata? 'child, young'

70. Tasaday batikənan 'lower leg, ankle area' Blit sokil, panintin 'lower leg, ankle area'

71. Tasaday bugal 'base (as of a tree)' Blit, KLM pasu 'base (as of a tree)'

72. Tasaday dawdaw 'be near' Blit, KLM dapag 'be near'

73. Tasaday dontot 'drink' Blit, KLM inam 'drink'

74. Tasaday kuməmil 'touch' Blit, KLm kuməbit 'touch'

75. Tasaday kundom 'eat' Blit, KLm kaßan 'eat'

76. Tasaday laginsinan (var. lagisinan) 'curly, of hair' Blit kulat 'curly, of hair'

77. Tasaday lagadol 'chin' Blit bəha?, KLm baha? 'chin'

78. Tasaday latəkok (var. ligtəkok) 'to vomit' Blit suwa, KLM suwah 'to vomit'

79. Tasaday palihan 'wind' Blit, KLM kalamag 'wind'

80. Tasaday lubad 'liver' Blit, KLM atay 'liver'

81. Tasaday talowon 'orphan' Blit, KLM nəجilu 'orphan'

82. Tasaday prglo?on 'sun' Blit, KLM agdaw 'sun'

83. Tasaday sagdigan ${ }^{12}$ 'hear, listen' Blit, KLM dinagan 'hear, listen'

84. Tasaday subəoan ${ }^{13}$ 'answer' Blit, KLM sagbi? 'answer' 
85. Tasaday tənək 'thorn'

Blit, KLM dugi 'thorn'

86. Tasaday tupasan 'soil, earth, ground'

Blit, KLM tana? 'soil, earth, ground'

Tasaday forms NOT shared with Blit or Klm, but found in other languages

87. Tasaday bəliwəs; Bon balliwəs ${ }^{14}$ 'dance'

Blit adal 'dance'; KLM sayaw, dalayaw 'dance'

88. Tasaday dələman; MвоSRN dələm; МвоBкD daləman 'night;

Blit, KLM sigəp 'night'

89. Tasaday duda; TAG dura?; SUBS, SBLBT dula? 'spit'

Blit, KLM ilab 'spit'

90. Tasaday huməs; MвоSRn aməs; МвоBкD haməs 'wet'; Bon Raməs 'take a bath'

Blit, KLM pala? 'wet'

91. Tasaday ku?ku?; ${ }^{15}$ Bon Puk?uk; SBLBT 'kuku? 'cough'

Blit, KLM buha? 'cough'

92. Tasaday lipot, ${ }^{16}$ Tboli lipot; МвоВкD, ILK lipat 'forget'

Blit, KLM lipəy 'forget'

93. Tasaday lisaha? 'head louse'; ${ }^{17}$ MвOSRn liseha? (< PMP *liseSeq) 'nit, louse egg'

Blit, KLM kutu 'head louse'

94. Tasaday liyan 'a natural hole in the ground'; Bon liyan 'cave'

Blit kokob 'a natural hole in the ground'; Kum toson 'hole'

95. Tasaday məlum 'afternoon'; NB: PMP *elem 'shade, darkness'

Blit mapun, KLM məhapun 'afternoon'

96. Tasaday sakat '18 'leg and hoof of an animal'; TAG, ITGB saka 'leg'

Blit səki, KLM kalamagin 'hoof of an animal'

Tasaday forms showing semantic extension

97. Tasaday balu't bayag 'head hair, eyebrow'

Blit, KLm balu't ulu 'head, skull'

98. Tasaday banag 'head, skull'

Blit bayag 'head, skull'

Note KLM subəy 'handle of a tool'.

In Bontok, balliwas is 'dance in a circle'. The form of the first vowel and the doubled consonant following it indicates that it is probably borrowed from one of the Cagayan Valley languages in which *ə $>a$, and reflects an earlier form *bəliwəs.

Also recorded as kalu?ku?, but this form was subsequently rejected.

Possibly a borrowing from Tboli.

Note that both KLM kutu, and TSD lisaha? loglog have the extended meaning of 'sparks throw off by a fire, flying ashes', implying that the Tasaday circumlocution here is a coinage of recent origin.

That this is not a borrowing from Tagalog or from some other language is suggested by the final $t$, probably a frozen genitive form found on certain other body parts in Tasaday, Blit, and Kulaman, e.g., balu't ulu 'hair of head'. 
99. Tasaday loglog 'fire'

Blit, KLM laglag 'flame'; Blit, KLM apuy 'fire'

100. Tasaday dita? 'blood, sap, resin'

Blit, KLM dita? 'sap, resin'; Blit nəpanug, KLM dəpanug 'blood'

101. Tasaday zpuy 'snake' (general term)

Blit əpuy 'snake species'; Blit ulad 'snake' (general term)

102. Tasaday matimbulu 'male genitals'

Blit, KLM bulu 'rounded, bulging'; Blit, KLm lasu? 'penis'

103. Tasaday bitbit 'to bring, to carry'

Blit, KLM bitbit 'to hold in one's free swinging hand'

Blit, KLM uwit 'carry'

104. Tasaday əlam (ag-) 'feel sick', (nək-) 'menstruate'

Blit pa?an (mo-) 'happen, be sick, menstruate'

Blit ha?a (nəkə-) 'menstruate'; KLM bulan (-ən) 'menstruate'

105. Tasaday ha?a (-um-) 'see, know, be acquainted with'; peha?a 'eye'

Blit, KLm ha?a (-um-) 'see'; Blit, KLM mata 'eye'

Blit, KLM kilala? 'know, be acquainted with'

106. Tasaday ilib 'cave, shelter, house'

Blit ilib 'cave'; KLM ilib 'boulder, stone face of a cliff'

Blit lawi? 'field shelter'; KLM lawi 'temporary shelter'; Blit, KLM dalasan 'house'

107. Tasaday kumabus 'rib cage'

Blit kamabus; KLM kumabus 'lower ribs'

108. Tasaday məlawis 'tree'

Klm lawis 'sapling'; Blit, Klm kayu 'tree'

109. Tasaday litay (-um-) 'walk the length of a fallen log'; lumitay 'monkey'

Blit, KLm litay (-um-) 'walk the length of a fallen log'; Blit, KLM ubal 'monkey'

110. Tasaday maliton 'female'

Blit, KLM maliton 'old woman; married woman with children'; Blit, KLM bayi 'female'

111. Tasaday malok 'chicken; bird'

Blit, KLM malok 'wild chicken'; Blit, KLM manuk 'domesticated chicken; bird'

112. Tasaday matuluk 'stone'

Blit matuluk 'kind of stone'; Blit, KLM batu 'stone'

113. Tasaday saba? (-an) 'hold in one's hand; grasp; get; receive'

Blit, KLM saba? (-an) 'hold in one's hand; grasp'; Blit, KLM kuwa 'get; receive'

114. Tasaday səbay 'moon'

KLM sabay 'first quarter of the moon'; Blit, KLM bulan 'moon'

115. Tasaday topas 'betel chew'; (-um-) 'to chew on, as betel, sugarcane'

Blit, KLM tәpas (-um-) 'to chew on, as sugarcane'; Blit, KLM mama? 'betel chew'

116. Tasaday ugah 'plaintain, wild banana, domesticated banana'

Blit ugah 'k.o. banana'; Blit, KLM sagin 'banana, generic'

\section{Tasaday forms showing semantic narrowing}

117. Tasaday daməs 'rain'

Blit, KLM daməs 'storm, wind and rain for several days' 
118. Tasaday lagas 'female genitals'

KLM lagas 'seed, fruit; female genitals (euphemism)'; Blit, KLM bati? 'female genitals'

\section{Tasaday forms showing semantic shift}

119. Tasaday dompol (-um-) 'have intercourse'

KLM dumpal (-um-) 'collide with something, bang into something'; Blit, KLM iyut (-um) 'have intercourse'

120. Tasaday $\partial l a P^{19}$ 'pain, injury'

KLM ola? 'crack, as in wood, glass, cement, etc.'; Blit, KLM sakit (mə-) 'pain, sickness';

Blit ladu (-in-) 'feel sick'; Blit, KLM pali (-an) 'injury, wound'

121. Tasaday ima (tig-) 'give'

KLM ima (әgрә-) 'feign to offer something to someone'; Blit, KLM bagay (ag-) 'give'

122. Tasaday kəlamag (pə-) 'have intercourse (euphemism)'

Blit, KLM kalamag 'wind'

123. Tasaday lakan 'tongue'

KLM ləkən 'shrink back, e.g., person anticipating attack, elastic after stretching'; Blit, KLM dila? 'tongue'

124. Tasaday lukasan 'father'

Blit lukas 'old man, married man', KLM lukas 'old man, old woman'; Blit, KLM əma? 'father'

125. Tasaday sagdig (-an) 'ear'; (-um-) 'hear, listen' ${ }^{20}$

Blit, KLM sagdig (-um-, i-) 'lean against'; Blit, KLm təlina 'ear'

126. Tasaday tabul 'water'

Blit, KLM təbulan 'spring, natural water source from ground'; Blit, KLM wayəg 'water'

127. Tasaday tolina (-um-) 'hear, listen'

Blit, KLM taliza 'ear'; Blit, KLM dinag (-um-) 'hear, listen'

128. Tasaday tigbas 'right hand'; (i-) 'to use one's right hand'; (-um-) 'strike with a bolo'

Blit, KLM tigbas (-um-) 'strike with a bolo or other tool'; Blit, KLM kuwanan 'right hand'

129. Tasaday $u k i t a n^{21}$ 'trail, path, road'

KLM ukitan 'to pass by or through'; Blit, KLM dalan 'trail, path, road'

Tasaday paraphrases and metaphorical extensions, post-1971

130. Tasaday bayi? 'clothes', (-um-) 'wear clothes'

Cf. bayi? 'k.o. ground orchid with wide leaves'

131. Tasaday basag lati? 'coconut palm'

Cf. basag 'sago palm', lati? 'brush, small trees; vegetation outside rain forest'

Blit, KLM ləpo? 'coconut'; lati? 'brush, small trees'

\footnotetext{
For example: du?ən ala? pəha? $k u$

there.is pain eye my

'My eye is painful.'

See also TsD tumalina 'hear, listen'.

Variant nukitan.
} 
132. Tasaday bəgiyay 'corn, maize'

Cf. bəgiyan 'k.o. rain forest plant'

Blit, KLm kalay 'corn, maize'

133. Tasaday bitog momo? dakal 'canned sardines'

Cf. bitog 'tadpole', momo? dakal 'Big Uncle'22

134. Tasaday butu? basag lati? 'fruit of the coconut palm'

Cf. butu? 'lump, rounded thing' (see basag lati? above)

Blit, KLM lapo? 'fruit of the coconut palm'

135. Tasaday da?un kayu 'money'

Cf. da?un 'leaf'; kayu 'tree'

Blit, KLm pilak 'money'

136. Tasaday hibatan 'mattress'

Cf. hibat 'lie down on one's back'

Blit tilam 'mattress'

137. Tasaday katilis mata 'to be drunk'

Cf. katilis 'turn, spin', mata 'eye'

Blit, KLM makəhilu 'to be drunk'

138. Tasaday kudit (-um-) 'to write'

Cf. kudit 'k.o. plant with leaf markings'

Blit, KLM sulat 'to write'

139. Tasaday kulinsuy 'flashlight'

Cf. kulinsuy 'fire drill'

Blit, KLM paslarit 'flashlight'

140. Tasaday luyuy molawis 'large brass gong'

Cf. luyu 'hidden', malawis 'wood, tree'

Blit, KLM salagi 'large brass gong'

141. Tasaday maghalin 'lowlander; those who move to the boundaries of the reservation'

Cf. TAG maghalin 'to move'

Blit kristiano 'Christian settler, lowlander'

142. Tasaday məbukəh balu't bayag 'Caucasian'

Cf. məbukəh 'write', balut't bayag 'hair of the head'

Blit amorikano 'Caucasian'

143. Tasaday natək momo? dakal 'husked or cooked rice'

Cf. natək 'palm starch', momo? dakal 'Big Uncle'

Blit, KLM bagas 'husked rice'

144. Tasaday ninan 'Moslem'

Cf. Blit ninan 'word commonly used by Moslems'

145. Tasaday pa?is tupasan 'shovel, pick, mattock'

Cf. pa?is 'tool', tupasan 'earth'

Blit pala 'shovel', sadul 'mattock' 
146. Tasaday pəla?pa? bəgiyay 'corncob'

Cf. pala?pa? 'growth (?)', bagiyay 'corn'

Blit tagbu 'corncob'

147. Tasaday pola?pa? ugah 'stalk of banana'

Cf. pola?pa? 'growth (?)', ugah 'banana'

Blit tagduk 'stalk of bananas'

148. Tasaday puyut dugi 'shoe, slipper'

Cf. puyut 'cloth bag', dugi 'thorn'

Blit, KLM talumpa? 'shoe'

149. Tasaday səkəg bayag 'pillow'

Cf. səkəg 'support', bayag 'head'

Blit dananan, KLM dananan 'pillow'

150. Tasaday tagu?an 'sheath of a bolo or knife'

Cf. tagu?an 'hiding place'

Blit, KLM guma? 'sheath of a bolo or knife'

151. Tasaday tinosoy malawis 'mortar'

Cf. tinoson 'hollowed', malawis 'wood, tree'

Blit, KLm losuy 'mortar'

152. Tasaday usa mata?as lisən 'horse'

Cf. usa 'large animal', mata?as 'long', lisən 'leg'

Blit kuda? 'horse'

153. Tasaday usa payawan 'water buffalo'

Cf. usa 'large animal', panawan 'having horns'

Blit, KLM kalabaw 'water buffalo'

\section{Tasaday paraphrastic expressions, pre-1971}

154. Tasaday amayan tabulan 'river'

Cf. amayan 'big', təbulan 'water + loc'

Blit dakal wayəg 'river'

155. Tasaday amayan haya?haya? 'thigh, upper leg'

Cf. amayan 'big', haya?haya? 'leg'

Blit, KLM bubun 'thigh, upper leg'

156. Tasaday amayan yuput 'molar'23

Cf. amayan 'big', yuyut 'tooth'

Blit biragay, KLm birigay 'molar'

157. Tasaday anayan tzbul 'fetch water'

Cf. ayayan 'go-for', təbul 'water'

Blit səkədu 'fetch water', KLM səkədu 'bamboo water container'

23 An alternative Tasaday term, bali?agay 'molar', was subsequently elicited. However, it should be noted that a number of circumlocutions for teeth appear in Errington and Errington's (1981) dictionary of the Kulaman dialect, for example, yipən ulu 'upper front teeth' (lit. 'teeth of head'), yipan baha? 'lower front teeth' (lit. 'teeth of chin'), and mipən tuyay 'eye teeth' (lit. 'teeth of dog'). 
158. Tasaday balu't məluk 'feather'

Cf. balu't 'hair-of', maluk 'bird'

Blit, KLm bulbul 'feather'

159. Tasaday balu't bayag 'eyebrow'

Cf. balu't 'hair of', bayag 'head'

Blit, KLm kalewey 'eyebrow'

160. Tasaday balu't pəha? 'eyelash'

Cf. balu't 'hair of', pəha?a 'eye'

Blit, KLm pilakpilak 'eyelash'

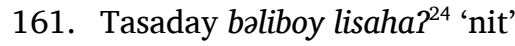

Cf. baliboy 'child', lisaha? 'head louse'

Blit kaliha? ${ }^{25}$ 'nit'

162. Tasaday buku haya?haya? 'knee'

Cf. buku 'lump', haya?haya? 'leg'

Blit buku lulud, ${ }^{26}$ KLM lulud 'knee'

163. Tasaday buku batikənan 'ankle'

Cf. buku 'lump', batikanan 'lower leg'

Blit sokil, panintin 'ankle'

164. Tasaday ilib sumakul ${ }^{27}$ 'field shelter'

Cf. ilib 'shelter', sumakul 'pound palm pith'

Blit lawi?, KLm lawi 'field shelter'

165. Tasaday limusay lugabuan 'dew'

Cf. limusay 'sweat', lugabuan 'sky'

Blit, KLM agmu? 'dew'

166. Tasaday matibulu lubad 'gall bladder'

Cf. matibulu 'lump', lubad 'liver'

Blit, KLM padu 'gall bladder'

167. Tasaday nə?uyat idə ${ }^{28}$ 'orphan'

Cf. nə?uyat 'dead', idə刀 'mother'

Blit, KLM nə?ilu 'orphan'

168. Tasaday nə?uyat tinəlomin 'widow, widower'

Cf. nə?uyat 'dead', tinalomin 'spouse'

Blit, KLm balu 'widow, widower'

169. Tasaday sagoysoy pəha?a ${ }^{29}$ 'tear'

Cf. sagoysoy 'drip', pəha?a 'eye'

Blit, KLM luha? 'tear'

This term may apply to the egg of the head louse. A different Tasaday term kuwol was subsequently elicited for 'nit'.

Or, Blit kaliha.

Lit. lump of lower leg.

Temporary shelter for preparation of palm starch.

tələwon 'orphan' was subsequently elicited.

Also recorded as tabul pəha?a (lit. 'water of eye') 
170. Tasaday suli? olom ${ }^{30}$ 'anwer'

Cf. suli? 'return', olom 'speech'

Blit, KLM sagbi? 'answer'

171. Tasaday tabul lawawan 'sweat'

Cf. təbul 'body', lawawan 'water'

Blit, KLM limusəy 'sweat'

172. Tasaday toso balitay 'navel'

Cf. toson 'hole', bəlitay 'umbilical cord'

Blit, KLM pusad 'navel'

173. Tasaday usa mə2idəb bələyus 'pig'

Cf. usa 'large animal', mə?idəb 'pointed', bələnus 'snout, nose'

Blit, KLm babuy 'pig'; usa 'deer'

\section{Manobo synonyms restricted in Tasaday}

174. Tasaday, Blit, KLM amayan; Blit, KLM dakal 'big'

175. Tasaday, Blit, KLM bukeh; Blit, KLM bula 'white'

\section{Phonological shift}

176. Tasaday dompol 'have intercourse'

KLM dumpal 'collide with something, bang into something'

177. Tasaday pondol (mi-) 'go'

Blit, KLM panaw (mi-) 'walk' 